\title{
Studies on Cobaltammines
}

\section{Association of Ammonia with the Hexammine Cobalt(III) Ion in Aqueous Solution}

\author{
RAG NAR LARSSO N
}

Department of Inorganic and Physical Chemistry, Chemical Institute, University of Lund, Lund, Sweden

\begin{abstract}
The solubilities of $\mathrm{Co}\left(\mathrm{NH}_{3}\right)_{6}\left(\mathrm{ClO}_{4}\right)_{3}$ and $\mathrm{Ba}\left(\mathrm{IO}_{3}\right)_{2}$ in $1 \mathrm{M} \mathrm{NH} \mathrm{NHO}_{4}$ are reported for mixed solvents, the non-aqueous component being ammonia, methanol, ethanol, acetone, glycerol and dioxane. Using these measurements, a method is devised for the calculation of the association constants when ammonia is associated with the $\mathrm{Co}\left(\mathrm{NH}_{3}\right)_{6}^{3+}$ ion. The first constant is reported. Evidence for an association of acetone with the $\mathrm{Co}\left(\mathrm{NH}_{3}\right)_{6}^{3}+$ ion is discussed. A spectrophotometric method is used which confirms the results from the solubility measurements.

From a solution containing some ammonium nitrate a solid phase has been isolated, having the composition $\left(\mathrm{Co}\left(\mathrm{NH}_{3}\right)_{6} \cdot \mathrm{NH}_{3}\right)$ $\left(\mathrm{ClO}_{4}\right)_{2} \mathrm{NO}_{3}$.
\end{abstract}

$\mathrm{T}^{\mathrm{s}}$ he hexammine cobalt(III) ion, a complex seemingly saturated with respect to further coordination, has been the subject of several investigations on ion association. For example, the association of sulphate or thiosulphate ions has been investigated conductometrically ${ }^{1}$ and spectrophotometrically ${ }^{2,3}$, by measurements of solubility ${ }^{4,5}$ and dialysis ${ }^{6}$ as well as by a polarographic method ?. Association of halide and pseudohalide ions has been studied both conductometrically $^{8}$ and spectrophotometrically ${ }^{9-11}$, whereas oxalate ion association has been studied by measurements of conductivity ${ }^{12}$ and dialysis ${ }^{6}$.

It must be noted, however, that some of the interpretations of these experimental data are not generally accepted.

It seemed to be of interest to investigate the association of an uncharged, polar molecule with the $\mathrm{Co}\left(\mathrm{NH}_{3}\right)_{6}^{3+}$ ion. No such measurements have apparently been made though several authors ${ }^{13,14}$ have pointed out the importance of such an association in determining the velocity of inner-sphere substitutions.

In the first part ${ }^{15}$ of this series it was reported that there is an increase in the solubility of $\mathrm{Co}\left(\mathrm{NH}_{3}\right)_{6}\left(\mathrm{ClO}_{4}\right)_{3}$ in $1 \mathrm{M} \mathrm{NH}_{4} \mathrm{ClO}_{4}$ as the concentration of ammonia is increased. This fact was then explained as the result of an outer- 
sphere ammine formation. In this work those solubility measurements have been extended in an effort to make possible the calculation of association constants.

As a check of the results obtained, an extinctiometric method has also been used.

\section{THEORY OF THE SOLUBILITY MEASUREMENTS}

The notations will be those of the preceding paper ${ }^{15}$ except when otherwise stated.

The reactions under investigation may be written in the general form:

$$
\mathrm{MA}_{6} \cdot \mathrm{mH}_{2} \mathrm{O}+\mathrm{n} \mathrm{A} \leftrightharpoons\left(\mathrm{MA}_{6}\right) \mathrm{A}_{\mathrm{n}} \cdot(\mathrm{m}-\mathrm{n}) \mathrm{H}_{2} \mathrm{O}+\mathrm{n} \mathrm{H}_{2} \mathrm{O}
$$

Excluding the solvating water, the conrresponding association constant is defined byl

$$
\beta_{\mathrm{n}}=\frac{\left[\left(\mathrm{MA}_{6}\right) \mathrm{A}_{\mathrm{n}}\right] f_{\left(\mathrm{MA}_{\mathrm{6}}\right) \mathrm{A}_{\mathrm{n}}} \cdot a_{\mathrm{aq}}{ }^{\mathrm{n}}}{\left[\mathrm{MA}_{6}\right] \cdot f_{\mathrm{MA}_{\mathrm{6}}} \cdot[\mathrm{A}]^{\mathrm{n}} \cdot f_{\mathrm{A}}{ }^{\mathrm{n}}}
$$

where brackets mean free concentrations and $f$ the activity coefficients of the species in question. $a_{\mathrm{aq}}$ is the activity of water. Now, $f\left(\mathrm{MA}_{\mathbf{6}}\right) \mathrm{A}_{\mathrm{n}}$ and $f_{\mathrm{MA}_{\mathbf{6}}}$ may be considered as almost equal, as they are related to ions of the same charge and almost nearly the same size. Thus eqn. (2) may be rewritten as

where $a_{\mathrm{A}}=[\mathrm{A}] \cdot f_{\mathrm{A}}$

$$
\beta_{\mathrm{n}}=\frac{\left[\left(\mathrm{MA}_{6}\right) \mathrm{A}_{\mathrm{n}}\right] \mathrm{a}_{\mathrm{aq}}{ }^{\mathrm{n}}}{\left[\mathrm{MA}_{6}\right] \cdot a_{\mathrm{A}}{ }^{\mathrm{n}}}
$$

We define $X=\sum_{\mathrm{n}=1}^{\mathrm{N}} \beta_{\mathrm{n}} \cdot a_{\mathrm{A}}^{\mathrm{n}} / a_{\mathrm{aq}}^{\mathrm{n}}$

Thus $\quad C_{\mathrm{M}}=\left[\mathrm{MA}_{6}\right](1+X)$

In a solution saturated with $\mathrm{MA}_{6}\left(\mathrm{ClO}_{4}\right)_{3}$, we have

$$
\left[\mathrm{MA}_{6}\right]\left[\mathrm{ClO}_{4}\right]^{3}=L
$$

and in the case when $C_{\mathrm{A}}=0$, i.e., $C_{\mathrm{M}}=\left[\mathrm{MA}_{6}\right]_{0}$, we have

$$
\left[\mathrm{MA}_{6}\right]_{0}\left[\mathrm{ClO}_{4}\right]_{0}^{3}=L_{0}
$$

If, as is the case in the present investigation, only the concentration of ammonia is changed, the salt medium being constantly kept $1 \mathrm{M} \mathrm{NH}_{4} \mathrm{ClO}_{4}$, and if $C_{\mathbf{M}}$ is low, we can put

$$
\left[\mathrm{ClO}_{4}\right]=\left[\mathrm{ClO}_{4}\right]_{0}
$$

Combining eqns. (6)-(8) we get

$$
\left[\mathrm{MA}_{6}\right] /\left[\mathrm{MA}_{6}\right]_{0}=L / L_{0}
$$

Inserting eqn. [9] into eqn. [5] we get

$$
1+X=\frac{C_{\mathrm{M}}}{\left[\mathrm{MA}_{6}\right]_{0}} \cdot \frac{L_{0}}{L}
$$

Knowledge of $L / L_{0}$ as a function of [A] would enable us to calculate $X$. Acta Chem. Scand. 12 (1958) No. 4 


\section{The evaluation of $L / L_{0}$}

With this purpose in mind we will consider the effects on the solubility of a sparingly soluble salt in an aqueous solution of high ionic strength when a part of the water is exchanged for another solvent, e.g., ammonia. This other solvent will be called here, for the sake of brevity, an "aquo-substitute".

The following items may be considered important:

1. The aquo-substitute may form complexes with the cation - or the anion - of the sparingly soluble salt.

2. A change in solvation conditions may result in a change in the "distance of closest approach" and thus cause activity changes of the ions in question.

3. The change in the dielectric constant of the solvent will cause a change in the activity coefficients of the ions. According to Owen ${ }^{16}$, two effects are operating: the primary and the secondary medium effects. The first one, arising from changes in ion-solvent interaction, is more or less correctly described by the theoretical equation of Born ${ }^{17}$ or by the empirical equation of Davies and Ricci ${ }^{18}$. However, it must be emphasized that none of those equations is generally valid. (Cf. Mayper, Clever and Verhoek ${ }^{19}$.) The secondary effect, connected with ion-ion interactions, is dependent on the ionic strength and is implied in the Debye-Hückel-Gronwall-LaMer equation.

One way to estimate the quotient $L / L_{0}$ for $\mathrm{Co}\left(\mathrm{NH}_{3}\right)_{6}\left(\mathrm{ClO}_{4}\right)_{3}$ in aqueous ammonia would be to use an ion of reference that does not form ammine complexes and is solvated as the $\mathrm{Co}\left(\mathrm{NH}_{3}\right)_{6}^{3+}$ ion. It should preferably be of the same size and have the same charge as this ion.

An ion fulfilling these demands is not easy to find, as most tervalent positive ions are hydrolyzed in aqueous ammonia, even at a high ammonium ion concentration.

As a reference ion $\mathrm{Ba}^{2+}$ has therefore been chosen. The measurements of Bjerrum 20, p. 145 indicate that this ion has a very low tendency of ammine formation.

However, the change of the solubilities of $\mathrm{MA}_{6}\left(\mathrm{ClO}_{4}\right)_{3}$ and a barium salt. are not directly comparable for obvious reasons.

To overcome this difficulty, we might try to find another aquo-substitute, call it $\mathrm{B}$, that does not form complexes with either $\mathrm{Co}\left(\mathrm{NH}_{3}\right)_{6}^{3+}$ or $\mathrm{Ba}^{2+}$ ions. Through a comparison of the solubility decrease of a barium salt in solutions of ammonia and in solutions of the aquo-substitute $B$, information might be obtained on the function $\left(L / L_{0}\right)_{\mathrm{MA}_{6}}$. We now make the following definitions:

The formal solubility product * of $\mathrm{Co}\left(\mathrm{NH}_{3}\right)_{6}\left(\mathrm{ClO}_{4}\right)_{3}$ is given by $l_{\mathrm{MA}_{6}}=$ $C_{\mathrm{MA}_{0}} \cdot C^{3} \mathrm{ClO}_{4}$. The formal solubility product of the barium salt to be used. $\left(\mathrm{BaX}_{2}\right)$ is given by $l_{\mathrm{Ba}}=C_{\mathrm{Ba}} \cdot C_{\mathrm{x}}^{2}$.

What we set out to measure is then the relative change of these formal. quantities, $l / l_{0}$, where $l_{0}\left(=L_{0}\right)$ means $l$ in solutions having $C_{\mathrm{B}}\left(C_{\mathrm{A}}\right)=0$.

The reasoning will proceed as follows: If no $\mathrm{MA}_{6}-\mathrm{B}$ nor any $\mathrm{Ba}^{2+}-\mathrm{A}$ or $\mathrm{Ba}^{2+} \mathrm{B}$ complexes are formed and if the solvation effects can be ignored, the quotients $\left(l / l_{0}\right)_{\mathrm{MA}_{\mathrm{e}}}$ and $\left(l / l_{0}\right)_{\mathrm{B} \text {. }}$ in the different solvents will depend only

* Note the difference between the usage of the symbol $l$ in this paper and in the preceding one ${ }^{15}$.

Acta Chem. Scand. 12 (1958) No. 4. 

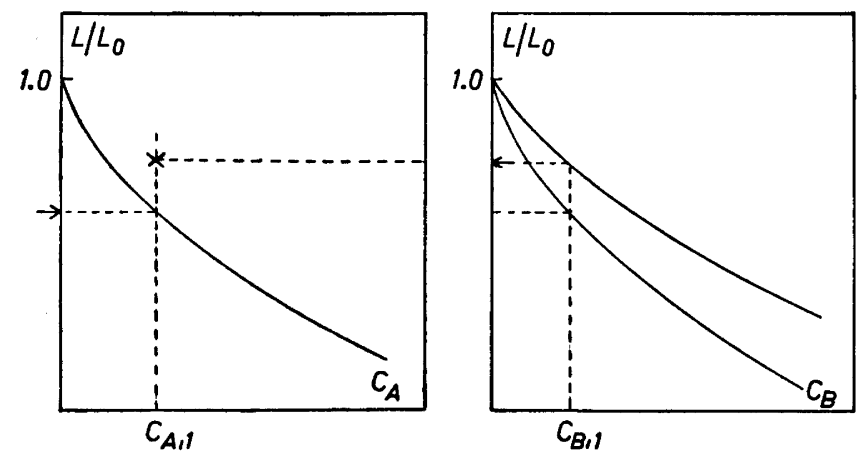

Fig. 1. Expected appearance of $\left(L / L_{0}\right) \mathrm{Ba}$ plotted against $C_{\mathrm{A}}$ (left figure) and $\left(L / L_{0}\right)_{\mathbf{M A}_{\mathrm{B}}}$ (right figure, upper curve) and $\left(L / L_{0}\right)_{\mathrm{Ba}}$ (right figure, lower curve) plotted against $C_{\mathrm{B}}$

on the dielectric constant of the solvent, as pointed out in item 3 previously mentioned. If now the quotients $l / l_{0}$, which in these special cases turn into $L / L_{0}$, are plotted against $C_{\mathrm{B}}$ - or $C_{\mathrm{A}}$ in the relevant case - we may expect curves of the form indicated in Fig. 1. For a certain value of $L / L_{0}$, indicated by an arrow in the left diagram, we find the concentrations $C_{\mathrm{A}_{1}}$ and $C_{\mathrm{B}_{1}}$ for which the solubility product of the barium salt is decreased to the same amount. According to the assumptions made, these solutions must then have the same dielectric constant. At $C_{\mathrm{B}}=C_{\mathrm{B}_{1}}$ we can read the value of $L / L_{0}$ of $\mathrm{Co}\left(\mathrm{NH}_{3}\right)_{6}$ $\left(\mathrm{ClO}_{4}\right)_{3}$ from the upper curve in the right diagram, indicated there by an arrow. This value of $L / L_{0}$, however, must be that of $\mathrm{Co}\left(\mathrm{NH}_{3}\right)_{6}\left(\mathrm{ClO}_{4}\right)_{3}$ at the concentration $C_{\mathrm{A}_{1}}$; this point is indicated by a cross in the left diagram.

Thus we may construct a set of points and from these draw a curve, describing the change of the solubility product of $\mathrm{Co}\left(\mathrm{NH}_{3}\right)_{6}\left(\mathrm{ClO}_{4}\right)_{3}$ in ammonia solution. This curve represents the function $L / L_{0}$ of eqn. (10) and insertion in this equation thus gives $X$, from which function the complexity constants may be obtained according to eqn. (4).

$$
\text { Calculation of } f_{\mathrm{A}} / a_{\mathrm{aq}}
$$

The standard state of the ammonia activity has been chosen so that $f_{\mathrm{NH}_{3}}=$ 1 in $1 \mathrm{M} \mathrm{NH}_{4} \mathrm{ClO}_{4}, C_{\mathrm{A}}=0$. The activity of water is put $=1$ in that same solution.

Following Bjerrum (Ref. ${ }^{20}$, p. 143) we assume that $f_{\mathrm{A}}$ as a function of $C_{\mathrm{A}}$ when $C_{\mathrm{NH}_{4} \mathrm{ClO}_{4}}=1 \mathrm{M}$ will run approximately parallel to $f_{\mathrm{A}}$ when $\mathrm{C}_{\mathrm{NH}_{4} \mathrm{ClO}_{\text {。 }}}$ $=0$.

Thus the vapour pressure data of Perman ${ }^{21}$ at zero ionic strength and $20^{\circ} \mathrm{C}$ can be used. From these it is found, if $C_{\mathrm{A}}<5 \mathrm{M}$,

$$
\begin{aligned}
& f_{\mathrm{A}}=1+0.066_{3} C_{\mathrm{A}}+0.00106 C_{\mathrm{A}}{ }^{2} \\
& a_{\mathrm{aq}}=1-0.0244 C_{\mathrm{A}}
\end{aligned}
$$




\section{EXPERIMENTAL}

As the sparingly soluble barium salt $\mathrm{Ba}\left(\mathrm{IO}_{3}\right)_{2}$ was chosen. In order to make the best possible choice of the aquo-substitute $\mathrm{B}$, the formal solubility products, $l$, for $\mathrm{Co}\left(\mathrm{NH}_{3}\right)_{6}$ $\left(\mathrm{ClO}_{4}\right)_{3}$ and $\mathrm{Ba}\left(\mathrm{IO}_{3}\right)_{2}$ were determined in $1 \mathrm{M} \mathrm{NH} \mathrm{NlO}_{4}$ at $20^{\circ} \mathrm{C}$ in aqueous solutions containing varying amounts of the following solvents: Methanol, ethanol, glycerol, acetone and dioxane.

For all these solvent mixtures the dielectric constant is known from the measurements of Åkerlöf ${ }^{22}$.

Chemicals used. The radioactive preparation of $\mathrm{Co}\left(\mathrm{NH}_{3}\right)_{6}\left(\mathrm{ClO}_{4}\right)_{3}$ was the same as in Part I15.

The barium iodate was prepared from solutions of reagent quality barium chloride and potassium iodate.

The ammonium perchlorate and ammonia solutions were prepared as in Part $\mathrm{I}^{15}$. The solutions of methanol, ethanol, glycerol and acetone were made from weighed amounts of absolute, acetone-free methanol, absolute ethanol, glycerol, p.a., heated to $180^{\circ} \mathrm{C}$ to expel water, and acetone, p.a., respectively. The dioxane, Eastman 2144, was purified according to Eigenberger ${ }^{23}$, and distilled at the constant boiling point $101.2^{\circ} \mathrm{C}$. The melting point was found to be $11.5^{\circ} \mathrm{C}$. The small amounts of impurities present certainly do not seriously affect the general features of the solubility curves.

Procedure. Solutions of $1 \mathrm{M} \mathrm{NH}_{4} \mathrm{ClO}_{4}, C_{\mathrm{B}} \mathrm{M} \mathrm{B}$ (or $C_{\mathrm{A}} \mathrm{M}$ A) were shaken with $\mathrm{Co} *\left(\mathrm{NH}_{3}\right)_{8}\left(\mathrm{ClO}_{4}\right)_{3}$ or $\mathrm{Ba}\left(\mathrm{IO}_{3}\right)_{2}$ in $100 \mathrm{ml}$ flasks at $20^{\circ} \mathrm{C}$ in a thermostatically controlled room for two days to ensure saturation. The method of separation and measuring of the cobalt solutions was the same as in Part $I^{15}$. The saturated solution of barium iodate was withdrawn with a $10 \mathrm{ml}$ pipette provided with a filter-stick. The iodate content was determined iodometrically. The solubility product, $l_{\mathrm{Ba}}$, was then easily calculated. As acetone and dioxane interfere in iodometric titrations, the solutions containing these solvents were freed from them before titration of the iodate content. The acetone solutions were made alkaline and boiled until all traces of ammonia were gone; it was then considered to be free from acetone also. The dioxane solutions were evaporated to dryness on the steambath. The quotient $l / l_{0}$ could be determined within $\pm 1 \%$ for $\mathrm{Ba}\left(\mathrm{IO}_{3}\right)_{2}$ and $\pm 2 \%$ for $\mathrm{Co}\left(\mathrm{NH}_{3}\right)_{6}\left(\mathrm{ClO}_{4}\right)_{3}$.

\section{RESULTS}

The quotients $l / l_{0}$ found are reported in Tables 1 and 2. Along with these are given values, $(D)_{I=0}$, of the dielectric constants of the solvent mixtures that should be valid if the ionic strength, $I$, was zero. They are arrived at from density determinations of the stock solutions employed and linear interpolation from the data of Åkerlöf ${ }^{22}$. As the curves given by Åkerlöf describing $D$ as a function of the concentration of aquo-substitute (given as weight-percent) are not exactly linear, the values of Tables 1 and 2 are not quite accurate, but they will serve well enough to give a rough picture of the dependency of $l / l_{0}$ on $D$. It must also be remembered that these values of $D$ are certainly not those of the actual solutions having an ionic strength $I=1 \mathrm{M} .(D)_{I=1}$ may be some $10 \%$ lower than $(D)_{I=0}$, (cf. Hasted, Ritson and Collie $\left.{ }^{24}\right)$. However, the quotient $\left(D_{0} / D\right)_{I=0}-D_{0}$ being the dielectric constant for $C_{\mathrm{B}}=0$ - will perhaps be more directly comparable to $\left(D_{0} / D\right)_{I=1}$ and has been used in Figs. 2 and 3.

It is seen that the curves of solubility of $\mathrm{Ba}\left(\mathrm{IO}_{3}\right)_{2}$ show the same relative positions as reported by Monk ${ }^{25}$ at zero ionic strength.

Now, if the curves $l / l_{0}$ versus $\left(D_{0} / D\right)_{I=0}$ for different aquo-substitutes coincide, it might be inferred that the assumptions made on the exclusive dependency of $l / l_{0}$ on $D$ are fulfilled. For $\mathrm{MA}_{6}\left(\mathrm{ClO}_{4}\right)_{3}$ this is the case in the 
Table 1. Corresponding values of $C_{\mathrm{B}}, l / l_{6}$ and $(D)_{I=0} \cdot \mathrm{Co}\left(\mathrm{NH}_{3}\right)_{6}\left(\mathrm{ClO}_{4}\right)_{3}$.

\begin{tabular}{|c|c|c|c|c|c|c|c|}
\hline \multicolumn{2}{|c|}{ Ammonia * } & \multicolumn{3}{|c|}{ Methanol } & \multicolumn{3}{|c|}{ Ethanol } \\
\hline $\begin{array}{c}C_{\mathrm{A}} \\
\mathbf{M} \\
\end{array}$ & $l / l_{0}$ & $\begin{array}{l}C_{\mathrm{B}} \\
\mathbf{M} \\
\end{array}$ & $l / l_{0}$ & $(D)_{I=0}$ & $\begin{array}{c}C_{\mathbf{B}} \\
\mathbf{M}\end{array}$ & $l / l_{0}$ & $(D)_{I}=0$ \\
\hline 0 & 1.00 & 0 & 1.00 & 80.4 & 0 & 1.00 & 80.4 \\
\hline 0.250 & 1.02 & 0.339 & 0.94 & 79.8 & 0.223 & 0.87 & 79.7 \\
\hline 0.500 & 1.05 & 0.508 & 0.88 & 79.6 & 0.557 & 0.78 & 78.8 \\
\hline 1.000 & 1.13 & 0.846 & 0.82 & 79.0 & 1.114 & 0.64 & 77.1 \\
\hline 1.500 & 1.23 & 1.354 & 0.74 & 78.2 & 1.560 & 0.55 & 75.8 \\
\hline 2.500 & $\begin{array}{l}1.47 \\
\end{array}$ & 2.030 & 0.64 & 77.2 & 1.782 & 0.50 & 75.2 \\
\hline 3.50 & 1.88 & 3.38 & 0.49 & 75.0 & 2.228 & 0.43 & 73.9 \\
\hline
\end{tabular}

\begin{tabular}{|c|c|c||c|c|c||c|c|c|}
\hline \multicolumn{3}{|c||}{ Glycerol } & \multicolumn{3}{c||}{ Acetone } & \multicolumn{3}{c|}{ Dioxan } \\
\hline \begin{tabular}{c|c|c|c|c|c|c|c|}
\hline$C_{\mathrm{B}}$ \\
$\mathrm{M}$
\end{tabular} & $l / l_{0}$ & $(D)_{I=0}$ & $C_{\mathrm{B}}$ & $l / l_{0}$ & $(D)_{I=0}$ & $C_{\mathrm{B}}$ & $l / l_{0}$ & $(D)_{I=0}$ \\
\hline & & & & & & & & \\
0 & 1.00 & 80.4 & 0 & 1.00 & 80.4 & 0 & 1.00 & 80.4 \\
0.237 & 0.95 & 79.8 & 0.223 & 0.99 & 79.6 & 0.128 & 1.00 & 79.2 \\
0.711 & 0.88 & 78.5 & 0.488 & 1.03 & 78.6 & 0.383 & 1.04 & 77.2 \\
1.185 & 0.84 & 77.3 & 0.863 & 1.10 & 77.3 & 0.511 & 1.05 & 76.2 \\
1.421 & 0.79 & 76.6 & 1.343 & 1.23 & 75.5 & 0.766 & 1.11 & 74.1 \\
1.895 & 0.75 & 75.4 & 1.678 & 1.31 & 74.2 & 1.021 & 1.15 & 72.0 \\
2.369 & 0.71 & 74.1 & 2.158 & 1.53 & 72.3 & 1.532 & 1.26 & 67.7 \\
\hline
\end{tabular}

* These values are obtained by graphical interpolation from the values reported in Table 1 of Part I ${ }^{15}$.

Table 2. Corresponding values of $C_{\mathrm{B}}, l / l_{0}$ and $(D)_{I=0} . \mathrm{Ba}\left(\mathrm{IO}_{3}\right)_{2}$.

\begin{tabular}{|c|c|c|c|c|c|c|c|}
\hline \multicolumn{2}{|c|}{ Ammonia } & \multicolumn{3}{|c|}{ Methanol } & \multicolumn{3}{|c|}{ Ethanol } \\
\hline $\begin{array}{l}C_{\mathrm{A}} \\
\mathbf{M}\end{array}$ & $l / l_{0}$ & $\begin{array}{l}C_{\mathrm{B}} \\
\mathrm{M}\end{array}$ & $l / l_{0}$ & $(D)_{I=0}$ & $\begin{array}{l}C_{\mathrm{B}} \\
\mathbf{M}\end{array}$ & $l / l_{0}$ & $(D)_{I=0}$ \\
\hline 0 & 1.00 & 0 & 1.00 & 80.4 & 0 & 1.00 & 80.4 \\
\hline 0.376 & 0.88 & 0.379 & 0.80 & 79.8 & 0.250 & 0.78 & 79.6 \\
\hline 0.872 & 0.71 & 0.569 & 0.71 & 79.5 & 0.624 & 0.52 & 78.6 \\
\hline 1.500 & 0.53 & 0.948 & 0.58 & 78.9 & 1.248 & 0.273 & 76.8 \\
\hline 2.013 & 0.41 & 1.516 & 0.40 & 78.0 & 1.747 & 0.172 & 75.3 \\
\hline 2.550 & 0.33 & 2.274 & 0.267 & 76.7 & 1.996 & 0.134 & 74.6 \\
\hline 3.62 & 0.209 & 3.79 & 0.111 & 74.3 & 2.495 & 0.083 & 73.1 \\
\hline
\end{tabular}

\begin{tabular}{|c|c|c|c|c|c|c|c|c|}
\hline \multicolumn{3}{|c|}{ Glycerol } & \multicolumn{3}{|c|}{ Acetone } & \multicolumn{3}{|c|}{ Dioxane } \\
\hline $\begin{array}{l}C_{\mathrm{B}} \\
\mathrm{M}\end{array}$ & $l / l_{0}$ & $(D)_{I=0}$ & $\begin{array}{l}C_{\mathrm{B}} \\
\mathrm{M}\end{array}$ & $l / l_{0}$ & $(D)_{I=0}$ & $\begin{array}{l}C_{\mathrm{B}} \\
\mathrm{M}\end{array}$ & $l / l_{0}$ & $(D)_{I=0}$ \\
\hline 0 & 1.00 & 80.4 & 0 & 1.00 & 80.4 & 0 & 1.00 & 80.4 \\
\hline 0.796 & 0.93 & 78.3 & 0.223 & 0.80 & 79.6 & 0.286 & 0.71 & 78.0 \\
\hline 1.327 & 0.90 & 76.9 & 0.558 & 0.55 & 78.4 & 0.572 & 0.54 & 75.7 \\
\hline 1.592 & 0.89 & 76.2 & 0.893 & 0.37 & 77.2 & 0.715 & 0.47 & 74.5 \\
\hline 2.122 & 0.87 & 74.8 & 1.339 & 0.231 & 75.5 & 1.144 & 0.268 & 70.9 \\
\hline 2.653 & 0.85 & 73.4 & 1.678 & 0.162 & 74.2 & 1.430 & 0.231 & 68.5 \\
\hline & & & 2.174 & 0.088 & 72.2 & 1.907 & 0.129 & 64.6 \\
\hline
\end{tabular}

Acta Chem. Scand. 12 (1958) No. 4 


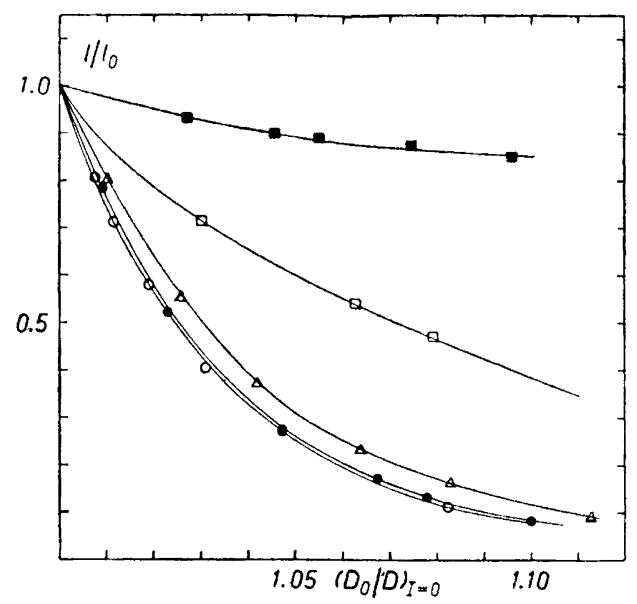

Fig. 2. The $\mathrm{Ba}\left(\mathrm{IO}_{3}\right)_{2}$ solubility curves; $l / l_{0}$ plotted against $\left(D_{0} / D\right)_{I=0}$. The symbols refer to the following aquo-substitutes: methanol (O); ethanol (O); acetone $(\triangle)$; dioxane $(\square)$; glycerol (口).

ethanol and methanol systems; for $\mathrm{Ba}\left(\mathrm{IO}_{3}\right)_{2}$ the ethanol, methanol and acetone curves lie rather close.

For these systems $l / l_{0}$ thus equals or nearly equals $L / L_{0}$ and the procedure indicated in Fig. 1 may be applied.

The measurements of Monk ${ }^{25}$, also including the propanols, show that as: the aquo-substitute molecule is made smaller, the solubility curves seem to converge to a common limit.

Thus, as ammonia, for which aquo-substitute we seek an analoque, is a. small molecule, and as methanol is the smallest molecule of the reference aquo-substitutes investigated and also fulfills the demands stated, methanol will be chosen as the aquo-substitute to be used in the following calculations.

\section{Discussion of anomalies}

The $l / l_{0}$-curves in dioxane and glycerol media do not coincide with the curves of the primary alcohol media (Figs. 2 and 3). Thus the change of the formal solubility products of the salts in question is not exclusively dependent on the dielectric constant of these solvents. Other factors must operate, such as an incorporation of the aquo-substitute in the solvation sheath of the ions (item 2 in the foregoing) or a complex formation (item 1 ). If a pure electrostatic attraction is operating, we should expect this effect to be greater for the $\mathrm{Ba}^{2+}$ ion than for the larger $\mathrm{Co}\left(\mathrm{NH}_{3}\right)_{6}^{3+}$ ion. The different courses of the curves of glycerol and dioxane media indicate that several factors are of importance, such as, e.g., the degree of selective solvation and the dimensions of the aquosubstitute molecules. This latter effect may perhaps be accounted for by assuming the operation of London dispersion forces as discussed by Bockris, Bowler-Reed and Kitchener ${ }^{26}$. 


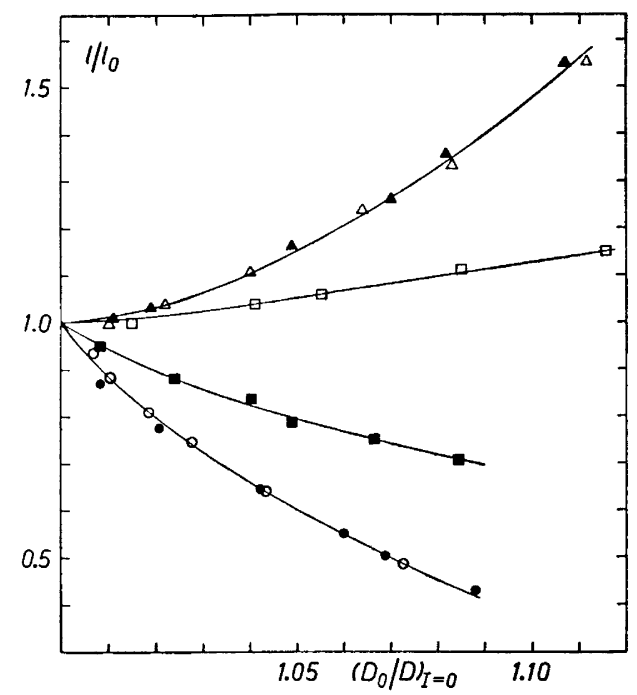

Fig. 3. The $\mathrm{MA}_{6}\left(\mathrm{ClO}_{4}\right)_{3}$ solubility curves; $l / l_{0}$ plotted against $\left(D_{0} / D\right)_{I=0}$. The symbols refer to the following aquo-substitutes: methanol (O); ethanol (@); glycerol (D); dioxane $(\square)$; acetone, when a small amount of chloride ions is present in the solutions $(\triangle)$; acetone, when perchlorate ions are the only anions in the solutions $(\boldsymbol{A})$.

Of course a distinction between a strongly selective solvation and complex formation is very difficult to make. In this connection reference ${ }^{27}$ may be made to the well-known glycerol compounds of the alkaline earth metals.

The solubility curves in the acetone medium, however, exhibit a different picture. The $\mathrm{Ba}\left(\mathrm{IO}_{3}\right)_{2}$-curve lies quite close to those of the primary alcohol media. The $\mathrm{Co}\left(\mathrm{NH}_{3}\right)_{6}\left(\mathrm{ClO}_{4}\right)_{3}$-curve, on the other hand, indicates an increase of solubility. If we attribute the solubility increase of $\mathrm{Co}\left(\mathrm{NH}_{3}\right)_{6}\left(\mathrm{ClO}_{4}\right)_{3}$ in ammonia solutions to an ammonia complex formation, we must for the sake of consequence infer a complex formation between acetone and the $\mathrm{Co}\left(\mathrm{NH}_{3}\right)_{6}^{3+}$ ion. This is not entirely inconceivable as examples of ketonic complexes are known, e.g., from the chemistry of the actinides (cf. Rydberg ${ }^{28}$ and references quoted there).

In a recent review Katzin ${ }^{20}$ has advanced the opinion that the increase in solubility found for salts in acetone-water solutions originates solely from an increased complex formation between the metal ion and the anions of the salt in question; this should be related to the small affinity of acetone for hydrogen ions and thus - according to Katzin - its small ability to compete with the anions for coordination sites when the water activity is diminished. However, it must be remembered that the parallel between complex formation and base strength, underlying that reasoning, holds true only for ligands of similar structure yielding pure $\sigma$-bonds; other factors would invalidate that parallelism.

Now, for practical reasons, the cobalt stock solution of the present work holds a certain amount of chloride ions, which are introduced in the solutions considered in concentrations of about $5 \mathrm{mM}$. Are these chloride ions responsible for the observed increase in solubility? The decisive experiment is, of course, to determine the solubility in solutions containing only perchlorate ions as anions - tacitly assuming that perchlorate ions do

Acta Chem. Scand. 12 (1958) No. 4 
Table 3. Corresponding values of $C_{\mathrm{A}}$ and $C_{\mathrm{B}}$ (B $=$ methanol) yielding corresponding

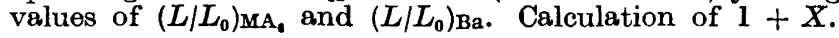

\begin{tabular}{|c|c|c|c|c|c|c|}
\hline $\begin{array}{l}C_{\mathrm{A}} \\
\mathrm{M}\end{array}$ & $\begin{array}{l}\left(L / L_{0}\right)_{\mathrm{Ba}} \\
\text { The ammo- } \\
\text { nia system }\end{array}$ & $\begin{array}{c}C_{\mathbf{B}} \\
\mathbf{M}\end{array}$ & $\begin{array}{l}\left(L / L_{0}\right)_{\mathbf{M A}_{6}} \\
\text { The metha- } \\
\text { nol system }\end{array}$ & $\begin{array}{l}\left(C_{\mathrm{M}} / C_{\mathrm{M}_{0}}\right)_{\mathrm{MA}} \\
\text { The ammo- } \\
\text { nia system }\end{array}$ & $1+X$ & $\frac{a_{\mathrm{A}}}{a_{\mathrm{aq}}}$ \\
\hline 0.100 & 0.964 & 0.057 & 0.986 & 1.007 & 1.021 & 0.101 \\
\hline 0.250 & 0.912 & 0.158 & 0.963 & 1.02 & 1.06 & 0.256 \\
\hline 0.500 & 0.827 & 0.328 & 0.927 & 1.05 & 1.13 & 0.523 \\
\hline 0.750 & 0.747 & 0.505 & 0.890 & 1.09 & 1.22 & 0.803 \\
\hline 1.000 & 0.668 & 0.703 & 0.851 & 1.13 & 1.33 & 1.094 \\
\hline 1.250 & 0.594 & 0.902 & 0.814 & 1.18 & 1.45 & 1.400 \\
\hline 1.500 & 0.526 & 1.103 & 0.781 & 1.23 & 1.57 & 1.716 \\
\hline 2.000 & 0.411 & 1.503 & 0.720 & 1.34 & 1.85 & 2.392 \\
\hline 2.500 & 0.328 & 1.915 & 0.658 & 1.47 & 2.24 & 3.12 \\
\hline 3.00 & 0.267 & 2.275 & 0.610 & 1.65 & 2.71 & 3.92 \\
\hline 3.50 & 0.213 & 2.633 & 0.565 & 1.88 & 3.32 & 4.77 \\
\hline
\end{tabular}

not form any complexes. Such measurements are reported in Fig. 2. The increase of solubility is not less than for the solutions containing chloride ions. Thus, in this case, an explanation as that proposed by Katzin ${ }^{20}$ must be ruled out.

\section{Calculations}

In the first two columns of Table 3 are given some values of $C_{\mathrm{A}}$ and the corresponding relative decrease of the solubility product of $\mathrm{Ba}\left(\mathrm{IO}_{3}\right)_{2}$ in ammonia solution, obtained by graphical interpolation from the data of Table 2. The third column contains the methanol concentrations that give the same relative decrease of $L_{\mathrm{Ba}}$, also obtained by graphical interpolation form Table 2. The relative decrease of $L_{\mathrm{MA}_{\mathrm{f}}}$, as obtained from the values of Table 1 , for these values of $C_{\mathrm{B}}$ is given in column 4 of Table 3 . This column thus gives $L / L_{0}$ of $\mathrm{MA}_{6}\left(\mathrm{ClO}_{4}\right)_{3}$ for the values of $C_{\mathrm{A}}$ in column 1 (Cf. Fig. 1). From the values of $\left(L / L_{0}\right)_{\mathrm{MA}}$ thus obtained and the corresponding values of $C_{\mathrm{M}} / C_{\mathrm{M}_{0}}$ given in column $5,1+X_{\mathrm{A}}$ has been calculated from eqn. (10).

In the definition of $\beta_{n}$ (eqn. (2)) we have used the free ligand concentration [A]. However, as $C_{\mathrm{A}}$ is large, $C_{\mathrm{M}}$ very small and the complexity very weak, the approximation $[\mathrm{A}]=C_{\mathrm{A}}$ is not an improper one and will be used in the following.

In the last column of Table $3 a_{\mathrm{A}} / a_{\mathrm{aq}}$ is calculated from eqn. (11). In Fig. 4 $X \cdot\left(a_{\mathrm{aq}} / a_{\mathrm{A}}\right)$ is plotted against $a_{\mathrm{A}} / a_{\mathrm{aq}}$. It is seen that there exists a linear relation between these two quantities.

If we take only the first two terms of eqn. (4) into consideration, it may be transformed to

$$
\frac{a_{\mathrm{aq}}}{a_{\mathrm{A}}} X=\beta_{1}+\beta_{2} \cdot \frac{a_{\mathrm{A}}}{a_{\mathrm{aq}}}
$$

Thus, from the above-mentioned linear relation the first two complexity constants may be obtained.

$$
\beta_{1}=0.24 \pm 0.05 \mathrm{M}^{-1} ; \beta_{2} \approx 0.05 \mathrm{M}^{-2}
$$




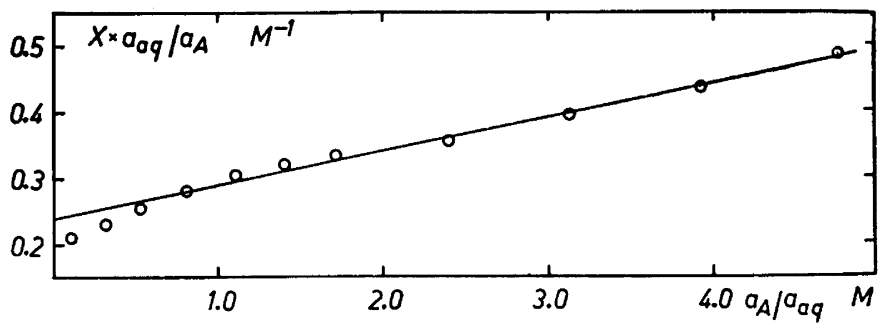

Fig. 4. $X \cdot \frac{a_{\mathrm{aq}}}{a_{\mathrm{A}}}$ as a function of $a_{\mathrm{A}} / a_{\mathrm{aq}}$.

However, if we assume the existence of the first complex only but take into consideration the increase of the complexity constant as the dielectric constant of the solvent diminishes $\left(c f\right.$. Ref $^{30}$ ), we also obtain a linear relation between $\frac{a_{\mathrm{aq}}}{a_{\mathrm{A}}} X$ and $\frac{a_{\mathrm{A}}}{a_{\mathrm{aq}}}$ :

Making the simplifying assumptions of linear dependency of $D$ on $C_{\mathrm{A}}$ and of $\beta_{1}$ on $D_{0} / D$, valid at not too large values of $D_{0} / D$, we may write

which equation becomes

$$
D=D_{0}-k C_{\mathrm{A}}
$$

and

$$
D_{0} / D=1+k^{\prime} C_{\mathrm{A}}
$$

$$
\beta_{1}=\left(\beta_{1}\right)_{0}\left(1+k^{\prime \prime} D_{0} / D\right)
$$

where $k, k^{\prime}$ and $k^{\prime \prime}$ are constants. Combining eqns. (13 b) and (14) we obtain the linear relation

Thus

$$
\beta_{1}=\left(\beta_{1}\right)_{0}\left(1+k^{\prime \prime}+k^{\prime} k^{\prime \prime} C_{\mathrm{A}}\right)
$$

$$
\frac{a_{\mathrm{aq}}}{a_{\mathrm{A}}} X=\beta_{1}=\left(\beta_{1}\right)_{0}\left(1+k^{\prime \prime}\right)+k^{\prime} k^{\prime \prime}\left(\beta_{1}\right)_{0} C_{\mathrm{A}}
$$

Or, as $C_{\mathrm{A}}$ is approximately proportional to $a_{\mathrm{A}} / a_{\text {aq }}$ (cf. eqns. (11)), $\frac{a_{\mathrm{aq}}}{a_{\mathrm{A}}} X$ will be a linear function of $a_{\mathrm{A}} / a_{\text {aq }}$, as in Fig. 4.

It is difficult to see how to distinguish between the effects of eqns. (12) and (16). At least we can say that a value of $\beta_{2}$ calculated from eqn. (12) must be a maximum value.

\section{FORMATION OF THE SOLID PHASE $\left[\mathrm{Co}\left(\mathrm{NH}_{3}\right)_{6} \mathrm{NH}_{8}\right]\left(\mathrm{ClO}_{4}\right)_{2} \mathrm{NO}_{2}$}

Some solubility measurements have also been carried out in a salt medium consisting of $0.150 \mathrm{M} \mathrm{NH}_{4} \mathrm{NO}_{3}$ and $0.850 \mathrm{M} \mathrm{NH}_{4} \mathrm{ClO}_{4}$.

The solubility curve then obtained is presented in Fig. 5. It is seen that at a certain value of the ammonia concentration the curve exhibits a distinct break, indicating that a new solid phase is formed. As the appearance of this Acta Chem. Scand. 12 (1958) No. 4 


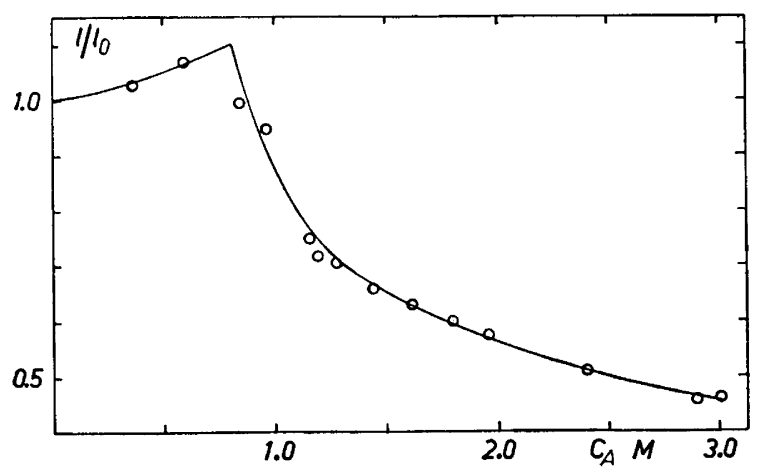

Fig. 5. $\left(l / l_{0}\right)_{\mathrm{MA}_{6}}$ as a function of $C_{\mathrm{A}}$ in a salt medium of the composition $0.850 \mathrm{M} \mathrm{NH}_{4} \mathrm{ClO}_{4}$, $0.150 \mathrm{M} \mathrm{NH} \mathrm{NO}_{3}$.

new phase is obviously dependent on the presence of both nitrate ions and ammonia, we may expect it to be of the general composition $\left(\mathrm{Co}\left(\mathrm{NH}_{3}\right)_{6}\right)$ $\left(\mathrm{NH}_{3}\right)_{\mathrm{x}}\left(\mathrm{ClO}_{4}\right)_{3-\mathrm{y}}\left(\mathrm{NO}_{3}\right)_{\mathrm{y}}$

Analysis of the solid phase. Some $\mathrm{Co}\left(\mathrm{NH}_{3}\right)_{6}\left(\mathrm{ClO}_{4}\right)_{3}$ - unlabelled - was shaken with $100 \mathrm{ml}$ of a solution of the following composition: $2.4 \mathrm{M} \mathrm{NH}_{3}, 0.15 \mathrm{M} \mathrm{NH}_{4} \mathrm{NO}_{3}$ and $0.85 \mathrm{M} \mathrm{NH}_{4} \mathrm{ClO}_{4}$. After a day the solid phase was separated and washed with alcohol until no ammonia could be detected, then washed with ether and air-dried. The substance thus obtained lost ammonia slowly on storage in open vessels at room temperature and rapidly at $100^{\circ} \mathrm{C}$. The dried substance was analyzed for nitrate content according to Lindo ${ }^{31}$ and for cobalt by a colorimetric determination of the $\mathrm{Co}\left(\mathrm{NH}_{3}\right)_{8}^{8+}$ ion at $472 \mathrm{~m} \mu$. $\left(\mathrm{NO}_{3}^{-}\right.$: Calc. for $\mathrm{Co}\left(\mathrm{NH}_{3}\right)_{6}\left(\mathrm{ClO}_{4}\right)_{2} \mathrm{NO}_{3} 14.7 \%$; Found $14.8 \%$, Co: Calc. $13.97 \%$; Found $13.96 \%$.)

If the ether-dried substance was rapidly weighed and thereafter dried at $100^{\circ} \mathrm{C}$, it lost $3.7 \%$ of its weight. (Calc. for [Co $\left.\left(\mathrm{NH}_{3}\right)_{6} \mathrm{NH}_{3}\right]\left(\mathrm{ClO}_{4}\right)_{2} \mathrm{NO}_{3} 3.9 \%$.) This result is in agreement with solid phase studies of Ephraim ${ }^{32}$ and of Spacu and Voishescu ${ }^{33}$, which indicate that $\left[\mathrm{Co}\left(\mathrm{NH}_{3}\right)_{6} \mathrm{NH}_{3}\right] \mathrm{Cl}_{3}$, though not stable, may be isolated at room temperature.

Thus we may conclude that the new solid phase is $\left[\mathrm{Co}\left(\mathrm{NH}_{3}\right)_{6} \mathrm{NH}_{3}\right]\left(\mathrm{ClO}_{4}\right)_{2}$ $\mathrm{NO}_{3}$. However, as the composition of the solid phase gives no direct information on the composition of the ionic species in solution, no further investigation was made.

\section{THE LIGHT ABSORPTION MEASUREMENTS}

The absorption spectrum of the $\mathrm{Co}\left(\mathrm{NH}_{3}\right)_{6}^{3+}$ ion in ammonia solutions has been investigated once by Nakatsuka ${ }^{34}$ who, however, reports no perceptible change with increasing ammonia concentration.

The low solubility of $\mathrm{Co}\left(\mathrm{NH}_{3}\right)_{6}\left(\mathrm{ClO}_{4}\right)_{3}$ and the weak complexity under consideration render a complete extinctiometric investigation impossible. However, an approximate method has been attempted, under the assumption that only the first complex is present in appreciable amounts. (For a complete theory see, e.g., Ahrland ${ }^{35}$.) In order to reach higher values of $C_{\mathrm{M}}$, the measurements have been performed at ionic strength $0.1 \mathrm{M}$. 
The following notations are used:

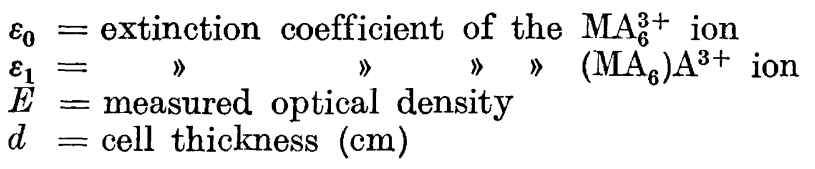

The quantity $\varepsilon_{\mathbf{M}}$ is defined by

Hence,

$$
E=d \varepsilon_{\mathrm{M}} C_{\mathrm{M}}
$$

$$
\varepsilon_{\mathrm{M}} C_{\mathrm{M}}=\varepsilon_{0}\left[\mathrm{MA}_{6}\right]+\varepsilon_{1}\left[\left(\mathrm{MA}_{6}\right) \mathrm{A}\right]
$$

Introducing the complexity constant $\beta_{1}$ from eqn. (3) we can rewrite eqn. (18)

$$
\varepsilon_{\mathrm{M}}-\varepsilon_{0}=\frac{\left(\varepsilon_{1}-\varepsilon_{0}\right) \beta_{1} \cdot[\mathrm{A}] \cdot f_{\mathrm{A}} / a_{\mathrm{aq}}}{1+\beta_{1} \cdot[\mathrm{A}] \cdot f_{\mathrm{A}} / a_{\mathrm{aq}}}
$$

If $q=\frac{\varepsilon^{\prime}{ }_{M}-\varepsilon_{0}}{\varepsilon^{\prime \prime}{ }_{M}-\varepsilon_{0}}$ where $\varepsilon^{\prime}{ }_{M}$ and $\varepsilon^{\prime \prime}{ }_{M}$ are measured at $C_{\mathrm{A}}=C_{\mathrm{A}}{ }^{\prime}$ and $C_{\mathrm{A}}{ }^{\prime \prime}$ respectively, and if we put $C_{\mathrm{A}}^{\prime}=[\mathrm{A}]^{\prime}$ and $C_{\mathrm{A}}{ }^{\prime \prime}=[\mathrm{A}]^{\prime \prime}$ we obtain from eqn. (19)

$$
\beta_{1}=\frac{q C_{\mathrm{A}}^{\prime \prime} f_{\mathrm{A}}^{\prime \prime} / a_{\mathrm{aq}}^{\prime \prime}-C_{\mathrm{A}}^{\prime} f_{\mathrm{A}}{ }^{\prime} / a_{\mathrm{aq}}^{\prime}}{C_{\mathrm{A}}^{\prime} f_{\mathrm{A}}^{\prime} / a_{\mathrm{aq}}^{\prime} \cdot C_{\mathrm{A}}^{\prime \prime} f_{\mathrm{A}}^{\prime \prime} / a_{\mathrm{aq}}^{\prime \prime}(1-q)}
$$

Here $f_{\mathrm{A}}^{\prime}$ and $a_{\text {aq }}^{\prime}$ denote the activity coefficient of $\mathrm{A}$ and water activity at $C_{\mathrm{A}}=C_{\mathrm{A}}^{\prime}$, etc.

These quantities are calculated from eqns. (11 a) and ( $11 \mathrm{~b}$ ) under the same assumption as before, i.e., that $f_{\mathrm{A}}$ and $a_{\mathrm{aq}}$ are functions dependent only on $C_{\mathrm{A}}$. This means that $f_{\mathrm{A}}$ and $a_{\mathrm{aq}}$ are now determined by the condition that $f_{\mathrm{A}}=1$ and $a_{\mathrm{aq}}=1$ in solutions $0.1 \mathrm{M} \mathrm{NH}_{4} \mathrm{ClO}_{4}, C_{\mathrm{A}}=0$.

From the paper ${ }^{35}$ referred to it follows that if other complexes than the first one also exist, the value of $\beta_{1}$ will be too small.

On the other hand, if only the first complex exists, as assumed here, but the determination is performed at a rather high ammonia concentration, the value of $\beta_{1}$ thus found will be greater than that valid at zero ammonia concentration, as follows from eqn. (15).

From these measurements we can thus expect only an indication of the order of magnitude of $\beta_{1}$.

Experimental. The measurements were performed in the ultraviolet wave length region, where outer-sphere association has previously been found to cause the greatest change in the absorption spectrum of the cobalt hexammine ion (Refs. ${ }^{2,3,9-11}$ ). The apparatus used was a Beckman Quartz Spectrophotometer (Model DU), changed as described by Adell ${ }^{36}$.

The solutions were all $5.00 \mathrm{mM}$ with respect to $\mathrm{Co}\left(\mathrm{NH}_{3}\right)_{8}\left(\mathrm{ClO}_{4}\right)_{3}$. The ionic strength was kept $0.1 \mathrm{M}$ by adding $\mathrm{NH}_{4} \mathrm{ClO}_{4}$. Four sets of measurements were made, with $C_{\mathrm{A}}=0,0.320,0.640$ and $0.960 \mathrm{M}$. The reference cell contained ammonia at the same concentration and so much of $\mathrm{NH}_{4} \mathrm{ClO}_{4}$ that the perchlorate concentration was equal to that in the other cell.

For $E>0.1$ the reproducibility was $\pm 2 \%$, which may be accepted in view of the great systematic errors of the method.

Acta Chem. Scand. 12 (1958) No. 4 
Table 4. Calculation of the quotient $q$ and $\beta_{1}$ from the experimental values of $\varepsilon_{M}$ and $\varepsilon_{0}$.

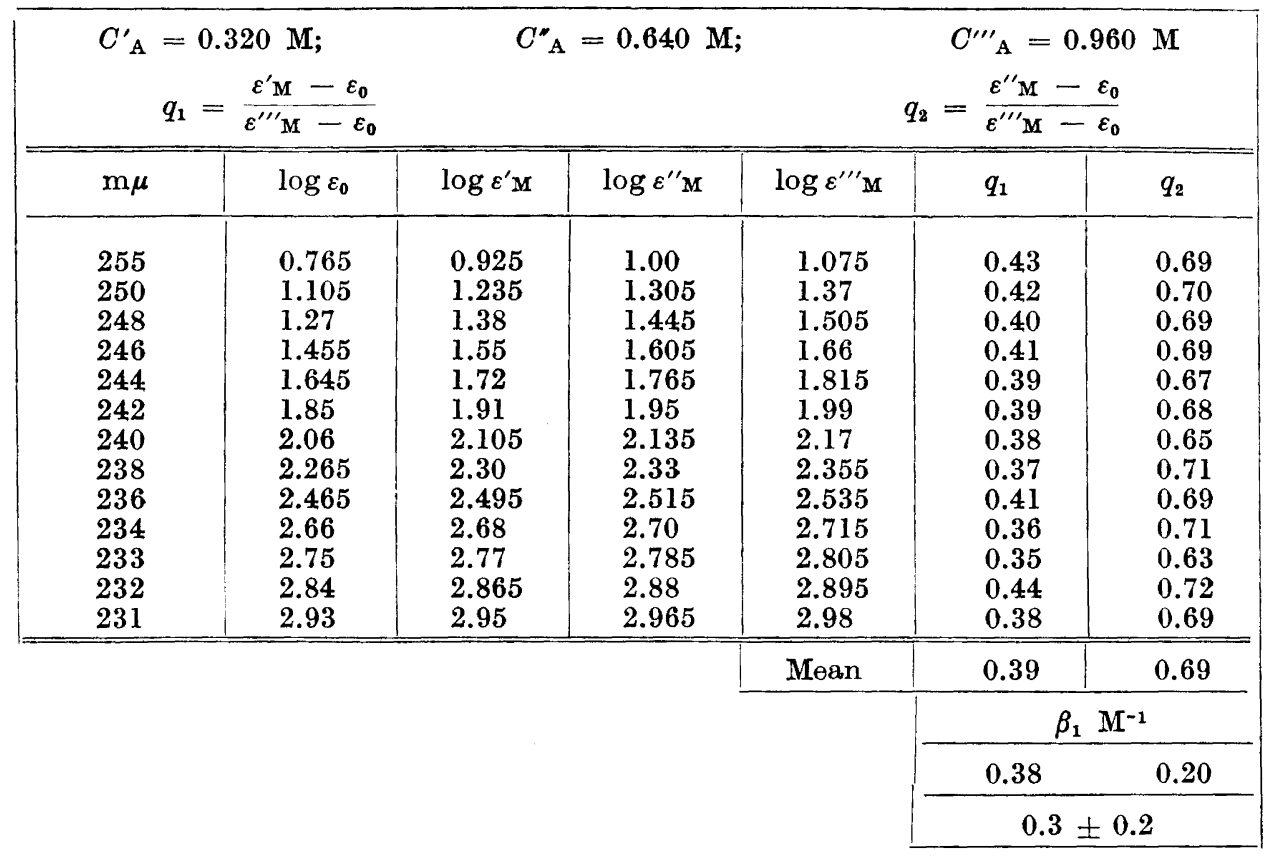

If we attribute the second-order term in $a_{\mathrm{A}} / a_{\mathrm{aq}}$, that was found from the solubility measurements, exclusively to the change in the dielectric constant we can introduce in eqn. (19) the correction:

$$
\beta_{1}=\left(\beta_{1}\right)_{0}+0.05 a_{\mathrm{A}} / a_{\mathrm{aq}}
$$

This gives us a second-order equation in $\left(\beta_{1}\right)_{0}$ which renders $\left(\beta_{1}\right)_{0}=0.44$ and 0.32 , valid at $C_{\mathrm{A}}=0$ and $I=0.1 \mathrm{M}$ and corresponding to the two values of $q$ of Table 4.

This correction thus reduces the relative spreading appreciably.

Results. In Table 4 the calculations are shown for those wave lengths where the shift of the extinction coefficients is large enough to permit calculations of some degree of accuracy.

\section{COMPARISON BETWEEN THE SOLUBILITY AND THE LIGHT ABSORPTION METHODS}

As different standard states have been used for $f_{\mathrm{A}}$ in the solubility measurements and in the light absorption measurements, the constants obtained are not directly comparable.

However, from theoretical considerations Bjerrum (Ref. ${ }^{20}$, p. 129) presents the formula,

$$
\log \beta=\log \beta_{0}+0.03 C_{\mathrm{NH}_{4}^{+}}
$$


where $\beta$ denotes the association constant for the association of one ammonia to a metal ion. Experimentally he finds very different values of the coefficient, both positive and negative ones, and especially for the reaction

$$
\mathrm{MA}_{5} \mathrm{H}_{2} \mathrm{O}+\mathrm{A} \rightleftharpoons \mathrm{MA}_{6}+\mathrm{H}_{2} \mathrm{O}
$$

he finds (Ref. ${ }^{20}$, p. 281) for the equilibrium constant $\beta$

$$
\log \beta=\log \beta_{0}+0.18 C_{\mathrm{NH}_{4}^{+}}
$$

If this surprisingly great coefficient is assumed to apply also for the very similar reaction considered here,

$$
\mathrm{MA}_{6}+\mathrm{A} \rightleftharpoons\left(\mathrm{MA}_{6}\right) \mathrm{A}
$$

we must conclude that $\beta_{1}$ at ionic strength $1 \mathrm{M}$ should be about $40 \%$ greater than at ionic strength $0.1 \mathrm{M}$.

Thus for ionic strength $1 \mathrm{M}$ we have:

$\beta_{1}=0.24 \pm 0.05 \mathrm{M}^{-1} \quad$ (solubility method)

$\beta_{1}=0.4 \pm 0.3 \mathrm{M}^{-1} \quad$ (light .abs. method)

If we prefer to make the "salt effect" correction with the help of eqn. (21), we obtain a smaller value $\beta_{1}=0.3 \pm 0.2 \mathrm{M}^{-1}$ (light abs. method).

Furthermore, if there exists a slight barium-ammonia complexity, which we have assumed not to be the case, the value of $\beta_{1}$ calculated from the solubility measurements should be somewhat greater. (The curve in the left diagram of Fig. 1 should be steeper and for a given value of $C_{\mathrm{A}}$ we should obtain a greater $X$ than that reported.)

To sum up, we can state that the results of the two methods are not inconsistent.

The author is indebted to Prof. S. Bodforss, Dr. B. Adell, Dr. S. Ahrland and Dr. S. Fronæus for their kind interest that has promoted this work.

\section{REFERENCES}

1. Posey, F. A. and Taube, H. J. Am. Chem. Soc. 78 (1956) 15.

2. Bale, W. D., Davies, E. W. and Monk, C. B. Trans. Faraday Soc. 52 (1956) 816.

3. Grimblett, F. G. R. and Monk, C. B. Trans. Faraday Soc. 51 (1955) 793.

4. Davies, C. W. J. Chem. Soc. 19302421.

5. Denney, T. O. and Monk, C. B. Trans. Faraday Soc. 47 (1951) 992.

6. Brintzinger, H. and Osswald, H. Z. anorg. u. allgem. Chem. 223 (1935) 253.

7. Laitinen, H. A., Frank, A. J. and Kivalo, P. J. Am. Chem. Soc. 75 (1953) 2865.

8. Jenkins, I. L. and Monk, C. B. J. Chem. Soc. 195168.

9. Linhard, M. Z. Elektrochem. 50 (1944) 224.

10. Evans, M. G. and Nancollas, G. H. Trans. Faraday Soc. 49 (1953) 363.

11. Kubota, T. J. Chem. Soc. Japan 75 (1954) 552.

12. Percock, J. M. and James, J. C. J. Chem. Soc. 19512233.

13. Adamson, A. W. and Basolo, F. Acta Chem. Scand. 9 (1955) 1261.

14. Ašperger, S. and Ingold, C. K. J. Chem. Soc. 19562862.

15. Larsson, R. Acta Chem. Scand. 11 (1957) 1405.

16. Owen, B. B. J. Am. Chem. Soc. 54 (1932) 1758.

17. Born, M. Z. Physik 1 (1920) 45.

18. Davies, T. W. and Ricci, J. E. J. Am. Chem. Soc. 61 (1939) 3274.

Acta Chem. Scand. 12 (1958) No. 4 
. 19. Mayper, S. A., Clever, H. L. and Verhoek, F. H. J. Phys. Chem. 58 (1954) 90.

20. Bjerrum, J. Metal Ammine Formation in Aqueous Solution, (Diss.) University, Copen. hagen 1941.

21. Perman, E. P. J. Chem. Soc. 83 (1903) 1168.

22. Åkerlöf, G. J. Am. Chem. Soc. 54 (1932) 4125; 58 (1936) 1241.

23. Eigenberger, E. J. prakt. Chem. 130 (2) (1931) 75.

24. Hasted, J. B., Ritson, D. M. and Collie, C. H. J. Chem. Phys. 16 (1948) 1.

25. Monk, C. B. J. Chem. Soc. 19512723.

26. Bockris, J. O'M., Bowler-Reed, J. and Kitchener, J. A. Trans. Faraday Soc. 47 (1951) 184.

27. Grün, A. and Husmann, J. Chem. Ber. 43 (1910) 1291.

28. Rydberg, J. Arkiv Kemi 8 (1956) 113.

29. Katzin, L. I. J. Inorg. \& Nuclear Chem. 4 (1957) 187.

30. Kratohvil, J. and Tě̌ak, B. Rec. trav. chim. 75 (1956) 775.

31. Lindo, D. Chem. News 58 (1888) 176.

32. Ephraim, F. Z. anorg. u. allgem. Chem. 147 (1925) 24.

33. Spacu, G. and Voichescu, P. Z. anorg. u. allgem. Chem. 243 (1940) 288.

34. Nakatsuka, Y. Bull. Chem. Soc. Japan 11 (1936) 629.

35. Ahrland, S. Acta Chem. Scand. 5 (1951) 1271.

36. Adell, B. Acta Chem. Scand. 4 (1950) 1.

Received February 22, 1958. 